\title{
The Applicability of Time Series Analysis in Real Estate Valuation**
}

\section{Introduction}

Passage of time plays an important role in real estate valuation. It results from the methodology of market analysis and determining the value, as set out in the regulations [11, 12] and in the literature, for example [1, 4].

An opinion prepared by a real property valuer is implemented based on market information. Most often these are transaction prices or rates of lease used to determine the expected income generated by a given real property. Due to the fact that they are subject to agreements concluded at different times in the past, they must be adjusted as to the valuation date. This adjustment must be based on market trends. Therefore, it is necessary to determine the directions in which these changes occur. According to the authors, time series are perfect for this purpose as they allow for the analysis of large data sets. In addition to the linear or non-linear dependency of unit transaction prices on time, it is also possible to capture seasonal fluctuations in real estate interest in a given market $[1,13,14]$.

It also seems that time series analysis as a method for forecasting the value $[9,10]$ could be included into a broader market statistical analysis in a comparative approach to valuation.

\section{Time Series Analysis}

Time series have been extensively described in $[2,3,6]$, among others. These are ordered sets of observations whose domain is the time. The main assumption of the time series analysis, which sets it apart from other common statistics, is the fact that its values are measured on figure scales, but usually at regular intervals. If the interval is irregular, we talk about fuzzy time series.

\footnotetext{
* AGH University of Science and Technology, Faculty of Mining Surveying and Environmental Engineering, Department of Geomatics, Krakow, Poland

** This work has been carried out within scientific research program no. 15.11.150.137/2013
} 
Depending on the data creating a time series, there are the following types:

- one-dimensional, i.e. sequences of the observed states of one variable, ordered by the value of time variable;

- multi-dimensional, which are formed by time series of multiple variables describing a specific object;

- one-dimensional cross-sectional, or sequences of the observed states of one variable, referring to the same period or moment to different spatial objects;

- multi-dimensional cross-sectional, which are formed by a cross-sectional series of multiple variables, considered at one time or period.

Regardless of the series type, systematic and random component can be determined from the data the series is formed by. Methods of analysis must therefore allow for filtering information in order to reduce the effect of noise.

The structure of most series can be defined by two basic components: the trend and the seasonal component. The trend specifies a general direction of the phenomenon development (linear or non-linear, increasing, decreasing or at constant level). On the other hand, the seasonal component indicates its repetition in regular time intervals. It may be represented by seasonal fluctuations (short-term) or cyclical fluctuations (long-term). In actual data, the trend and the seasonal component occur mostly together, connected in the additive, multiplicative or additive-multiplicative manner. A typical connection of time series components has been shown in Figure 1.

constant level

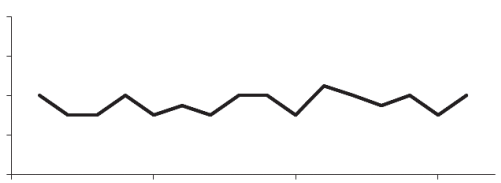

lack of seasonal factor

seasonal fluctuations
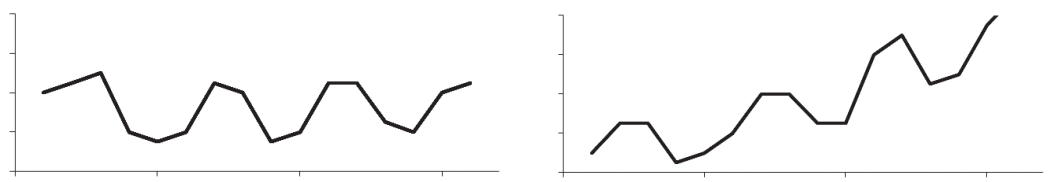

cyclical fluctuations
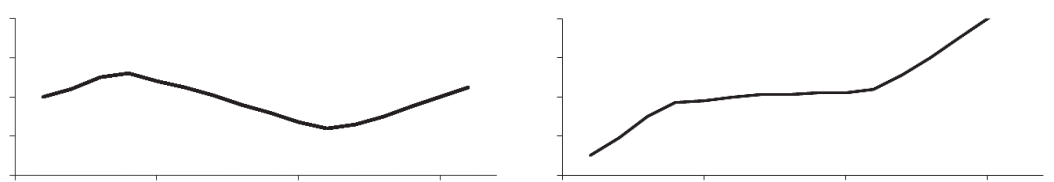

Fig. 1. Time series with different combinations of components 
Table 1. Characteristics of analysis and forecasting methods

\begin{tabular}{|c|c|c|c|}
\hline Method & $\begin{array}{l}\text { Components of } \\
\text { a series }\end{array}$ & Time of prediction & Characteristics \\
\hline Naive & \multirow{4}{*}{$\begin{array}{l}\text { constant level and } \\
\text { random factor }\end{array}$} & \multirow{4}{*}{ one period } & $\begin{array}{l}\text { easy calculations, } \\
\text { fast prediction, } \\
\text { poor quality of prediction }\end{array}$ \\
\hline Moving averages & & & \multirow{3}{*}{$\begin{array}{c}\text { easy calculations, } \\
\text { fast prediction, } \\
\text { problems with parameter selection }\end{array}$} \\
\hline $\begin{array}{l}\text { Weighted moving } \\
\text { averages }\end{array}$ & & & \\
\hline \begin{tabular}{||l} 
Exponential \\
smoothing - \\
a simple model
\end{tabular} & & & \\
\hline $\begin{array}{l}\text { Exponential } \\
\text { smoothing - } \\
\text { Holt model }\end{array}$ & \multirow{3}{*}{$\begin{array}{l}\text { trend } \\
\text { and random factor }\end{array}$} & $\begin{array}{l}\text { short-term } \\
\text { prediction }\end{array}$ & $\begin{array}{c}\text { flexible, } \\
\text { problems with parameter selection }\end{array}$ \\
\hline Linear regression & & \multirow{3}{*}{$\begin{array}{l}\text { short- and } \\
\text { intermediate-term } \\
\text { prediction }\end{array}$} & $\begin{array}{l}\text { easy calculations, possibility to } \\
\text { determine a prediction error }\end{array}$ \\
\hline $\begin{array}{l}\text { Creeping trend } \\
\text { with harmonic } \\
\text { weights }\end{array}$ & & & $\begin{array}{l}\text { possibility to determine a prediction } \\
\text { error, trend adaptation, } \\
\text { complex calculations, } \\
\text { problems with parameter selection }\end{array}$ \\
\hline $\begin{array}{l}\text { Ratio analysis } \\
\text { method }\end{array}$ & \multirow{5}{*}{$\begin{array}{l}\text { trend or constant } \\
\text { level, random } \\
\text { factor and } \\
\text { seasonality }\end{array}$} & & $\begin{array}{l}\text { possibility to determine an error, } \\
\text { complex calculations }\end{array}$ \\
\hline \begin{tabular}{|l} 
Exponential \\
smoothing - \\
Winters model
\end{tabular} & & $\begin{array}{l}\text { short-term } \\
\text { prediction }\end{array}$ & $\begin{array}{c}\text { possibility to determine a prediction } \\
\text { error, } \\
\text { complex calculations, } \\
\text { problems with parameter selection }\end{array}$ \\
\hline ARIMA & & $\begin{array}{l}\text { short- and } \\
\text { intermediate-term } \\
\text { prediction }\end{array}$ & $\begin{array}{l}\text { good quality of predictions, analysis } \\
\text { of large data sets only, requires } \\
\text { stationarity of time series, difficulties } \\
\text { with parameter selection }\end{array}$ \\
\hline $\begin{array}{l}\text { Homologous } \\
\text { period trend } \\
\text { estimation }\end{array}$ & & $\begin{array}{l}\text { short-term } \\
\text { prediction }\end{array}$ & $\begin{array}{l}\text { possibility to determine a prediction } \\
\text { error, difficulties with parameter } \\
\text { selection }\end{array}$ \\
\hline Harmonic analysis & & $\begin{array}{c}\text { short- and } \\
\text { intermediate-term } \\
\text { prediction }\end{array}$ & $\begin{array}{l}\text { possibility to determine a prediction } \\
\text { error, complex calculations }\end{array}$ \\
\hline
\end{tabular}


Identification of the time series structure should begin by eliminating the random component. It is performed through so-called smoothing, associated with local averaging of measurement data resulting in the mutual cancellation of unsystematic components of individual observations (mechanical smoothing using moving averages or a median). Smoothed time series are approximated by functions of various forms. Approximations can also be performed immediately, the smoothing function with analytical methods.

In order to determine the trend, a function fitted into the series of must be linear. If the series is monotonic, in most cases, such an approximation is possible. If, however, nonlinear components occur, earlier linearization will be required. In practice, this means that in order to determine the trend in time series data, it is enough to determine the Pearson product-moment correlation coefficient, defining the level of dependency of the studied phenomenon on the passing time.

Seasonality, in turn, can be determined for example by autocorrelation or partial autocorrelation. They will verify the extent to which a component of the time series depends on the preceding ones. It is also possible to carry out a one-way analysis of variance, making a hypothesis of equality of multiple average values.

In order to be able to properly analyze a time series, its components shall meet the following criteria:

- time series must be uniform (data refers to equal time intervals or specific moments),

- time units in a sequence must be equal (the same length of time interval or equal time interval between specific moments),

- the analysis period must comprise the interval in which the same factors operate on the studied phenomenon.

It should be noted that if random errors are not large, the identification of time series components can be performed through a visual analysis of the graph shape. A clear monotonic trend determines the shape of the graph. It then reminds a line parallel to the X-axis or a straight line inclined to it. Seasonality is then a pattern repeated on the graph.

Knowledge of a mathematical model of the process described by a time series allows us to generate a prediction of the analyzed phenomenon on its basis. The choice of an analysis and forecasting method depends on the type of a series and on the horizon estimation. A summary of the most common methods has been presented in Table 1.

\section{Time Series in Real Estate Valuation}

Due to the fact that real estate transaction prices are arranged us in a function of time, they can be perceived as a time series. If we form a sequence composed of prices alone, it will be a one-dimensional cross-sectional series. However, if additionally 
real estate will be described by attributes, it will be a multi-dimensional cross-sectional series.

As is appears from the considerations above (Section 2), the purpose of the time series analysis is to identify the essence of the phenomena described by them or to forecast their future values. Therefore, the authors propose to use time series in real estate valuation for:

- the analysis of a trend of price changes in time,

- determining the market value of real estate.

While carrying out real estate valuation in the comparative or blended approach, property valuers base their opinion on transactions concluded in the past, relating to a group of real properties with attributes and use similar to the real property which is being valued. Thus, they have to cope with out-of-dateness of the information about the unit prices.

There are two methods:

1) Valuation using the unit transaction prices adjusted for time, having previously performed a time adjustment of real estate transaction prices similar to the valued one, on the valuation date which precedes the adjustment of prices due to other market characteristics.

2) Taking into consideration the time elapsed from the date of the transaction, in the statistical analysis of the transaction price volatility, as an attribute describing real estates similar to the one being valued.

Adjustment of unit transaction prices due to the passage of time is performed through various mathematical models $[4,5,7]$. The simplest of these is, of course, the interval model, in which the coefficient of variation of the price per unit of time is calculated as the product of the transaction price difference and the time difference. It requires a small number of real properties (at least 4), but it must be carried out on real properties with the attributes identical to the attributes of the real estate being valued. Extreme transactions must be set apart relative to each other by about nine months. Therefore, it is not used for general real estate market analysis.

Other models described in the literature (i.e. non-linear regression and a multiplicative model), are based on the much more sophisticated calculations. Hence, when used, it is possible to determine the coefficient of variation of prices based on real properties with similar attributes. Extreme transactions used for the calculations must be set apart relative to each other by at least 12 months.

The process of considering the time as an attribute in the statistical analysis of the volatility of real estate prices starts from determining its correlation with transaction prices. It is therefore, in some way, a source of an idea to use time series for the analysis of the trend of price changes in time. While referring to the method of determining the components of time series - it is the beginning of the performance of such an analysis. Another factor, of course, will be determining seasonality. 
For a time series of unit transaction prices to meet the above-mentioned requirements (Section 2), the data must be properly prepared. The elapsing time should be perceived as a set of consecutive, equally spaced intervals. It seems natural to adopt them as consecutive months that have passed since the first transaction in the series. Transaction prices should be attributed to each interval created in this way. Since the information forming a series relates to similar real properties, it is suggested to average unit prices for the transactions concluded in the consecutive months.

It is also possible to go a step further and, on the basis of a time series, try to forecast the market value of a real property. The individual elements of the analyzed series would have to be real estate unit transaction prices with the attributes identical to the attributes of the real estate being valued. However, taking into account how large this database with the real estate identical to the one being valued would have to be, it seems virtually impossible to be able to determine its value based on the time series analysis.

It is therefore proposed to perform a valuation based on a large set of data, which will be unified and reduced by:

- the analysis of the variability of unit transaction prices to determine the effect of individual attributes on them (except for the time);

- the adjustment of prices in time series for all the market attributes affecting them (except for the time), so that the attribute values were aligned with the parameters used to describe the real property being valued;

- the determination of averages, adjusted with respect to the attributes of transaction prices, in the accepted unit of time.

The discussed valuation method would fit into the method of market statistical analysis in the comparative approach.

\section{Analysis of a Sample Time Series}

In order to verify the applicability of time series analysis in valuation, information was collected on 295 transactions regarding agricultural land. All the real properties have the same attributes: location, surroundings, shape and topography, agricultural condition, communication (access to a road).

The analyzed period should not exceed two years [8]. However, the regulations allow for exceptions to this rule, therefore the first recorded transaction took place in January 2010 while the last one in December 2013. The basic characteristics of the database established in this way have been contained in Table 2.

Table 2. Characteristics of the database used for the valuation

\begin{tabular}{|c|c|c|c|c|c||}
\hline $\begin{array}{c}\text { Number of } \\
\text { transactions }\end{array}$ & $\begin{array}{c}\text { Average } \\
\text { transaction price } \\
{\left[\mathrm{PLN} / \mathrm{m}^{2}\right]}\end{array}$ & $\begin{array}{c}\text { Median of } \\
\text { transaction prices } \\
{\left[\mathrm{PLN} / \mathrm{m}^{2}\right]}\end{array}$ & $\begin{array}{c}\text { Minimum } \\
\text { transaction price } \\
{\left[\mathrm{PLN} / \mathrm{m}^{2}\right]}\end{array}$ & $\begin{array}{c}\text { Maximum } \\
\text { transaction price } \\
{\left[\mathrm{PLN} / \mathrm{m}^{2}\right]}\end{array}$ & $\begin{array}{c}\text { Standard } \\
\text { deviation } \\
{\left[\mathrm{PLN} / \mathrm{m}^{2}\right]}\end{array}$ \\
\hline \hline 295 & 1.15 & 1.00 & 0.31 & 3.23 & 0.54 \\
\hline
\end{tabular}


Unit prices are poorly correlated with transaction time (Fig. 2). The Pearson product-moment correlation coefficient is positive $(r=0.10)$, indicating an increase in the prices in the market subject to the analysis, over the four analyzed years. It is also the information about the first component of the time series - an increasing trend.

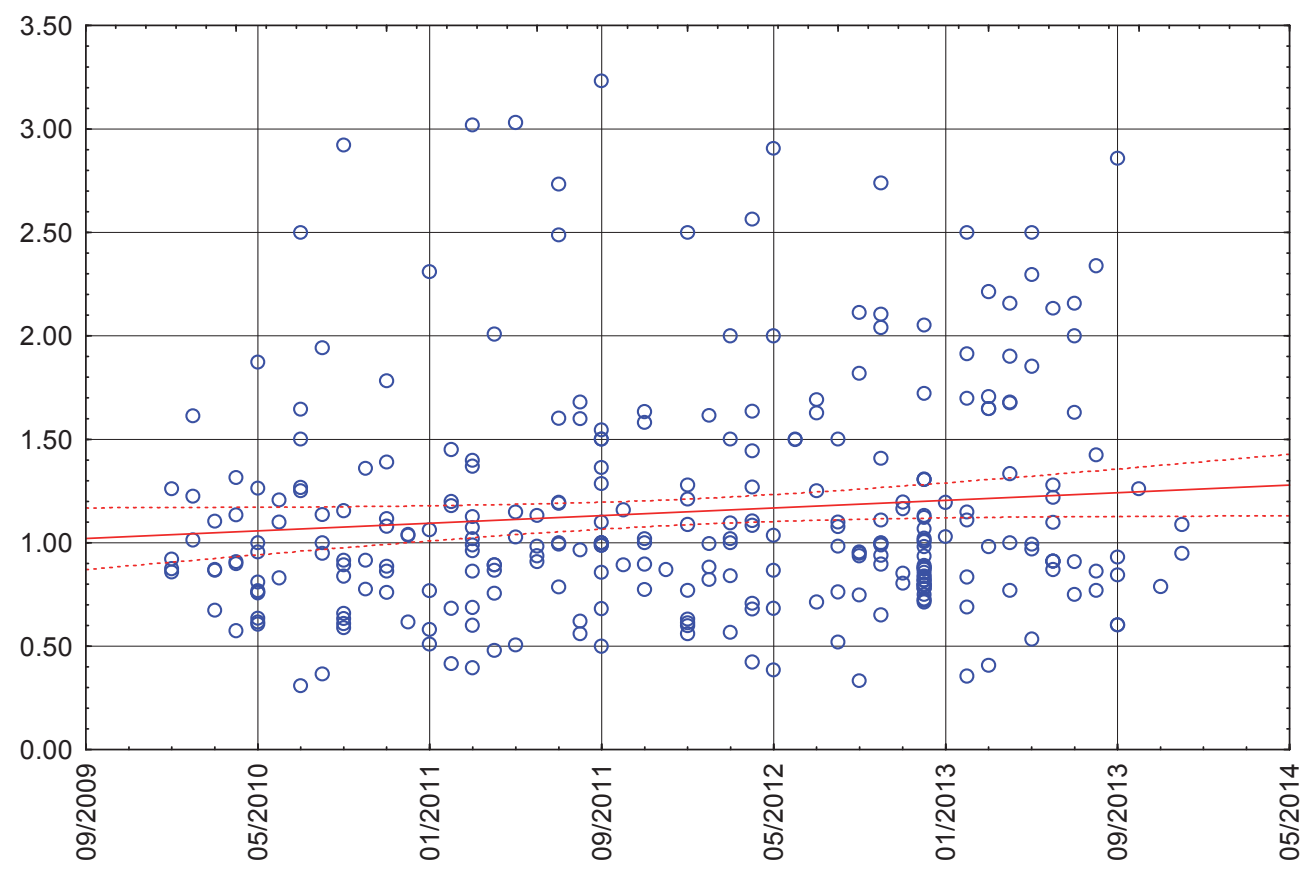

Fig. 2. Correlation of individual transaction prices with transaction time

Due to the fact that the real estate in the analyzed set have the same characteristics, it is not necessary to determine the effect of individual attributes on the prices or to adjust these prices. It was enough only to calculate their average values of individual months. In this way, a time series consisting of 48 monthly periods was created, which has been presented in Figure 3.

Basing on the shape of the graph, it is difficult to verify the trend of the series, and determining seasonality is in fact impossible. That is why it has been smoothed by the method of moving averages (Fig. 4).

The downward trend was confirmed here (an increasing trend). Seasonality also became noticeable. From December to May each year, unit real estate prices rise, but from July to November they fall. These are seasonal fluctuations.

The assessment of a market value was based on an additive model. In January 2014, it amounted to $1.34 \mathrm{PLN} / \mathrm{m}^{2}$, and in the following months it should have remained at the same level (Fig. 5). 


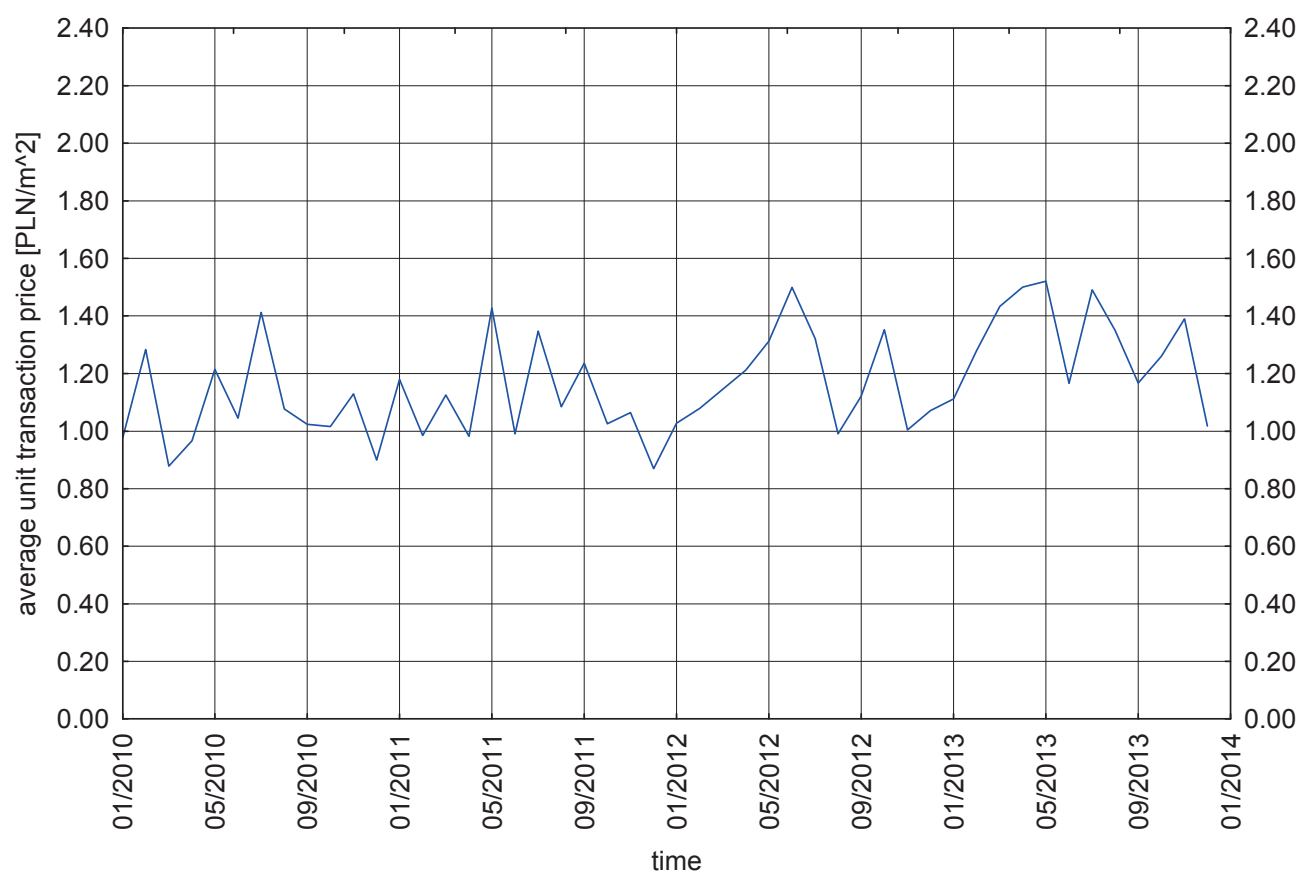

Fig. 3. Time series of average unit prices

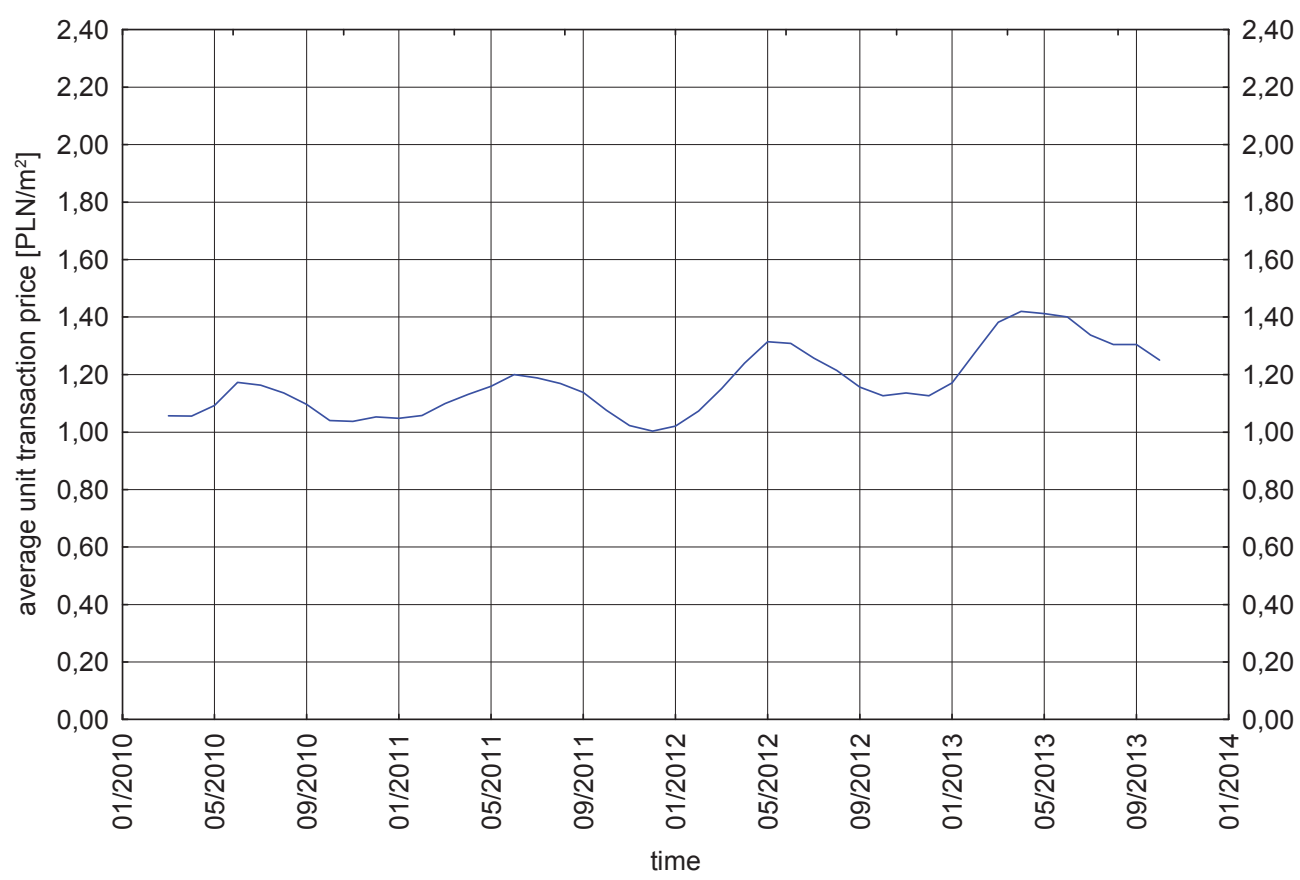

Fig. 4. Smoothing by the method of moving averages 


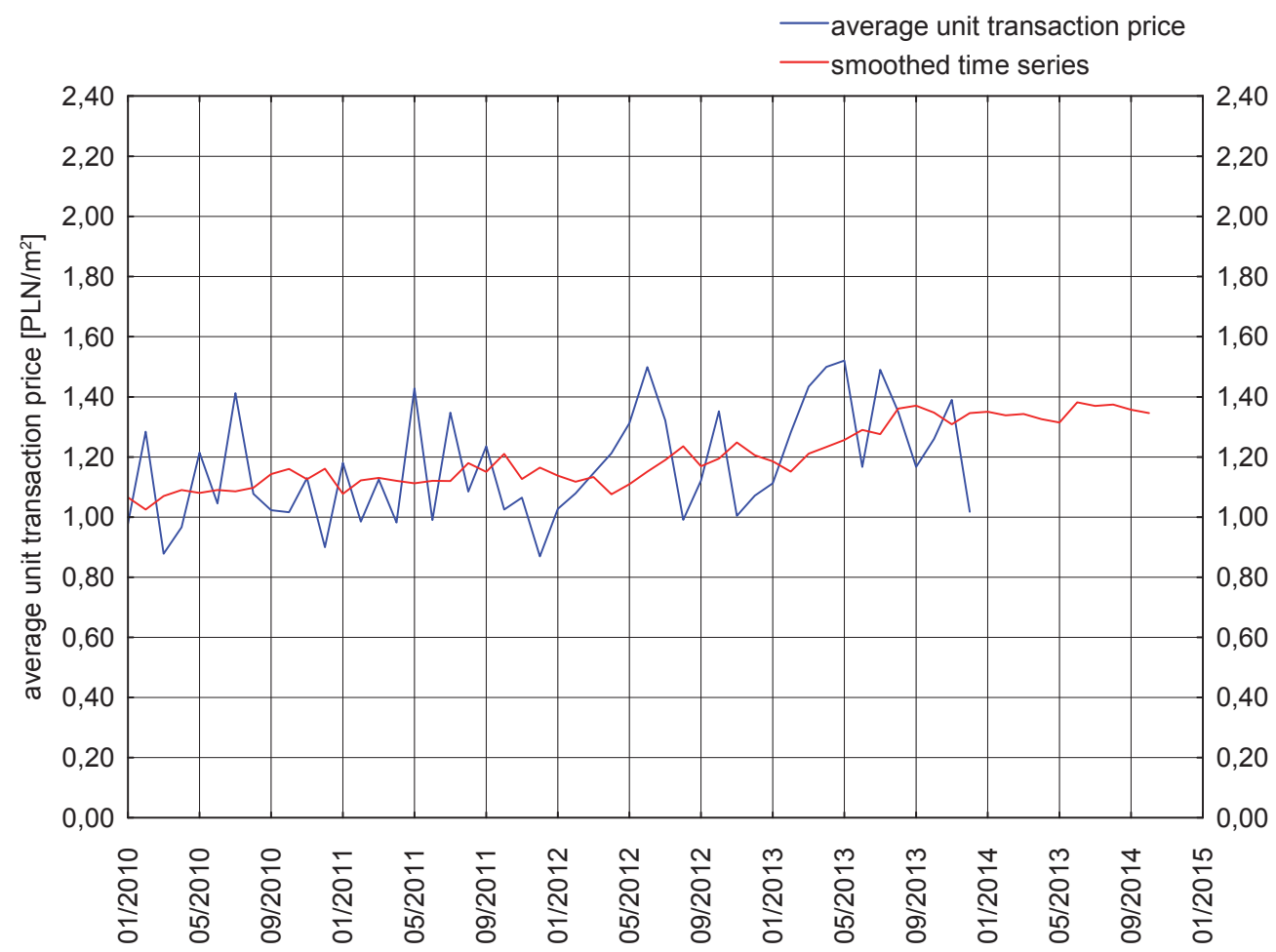

Fig. 5. Forecast of the market value

Specific assumptions adopted to simplify calculations and a practically negligible effect of time on transaction prices (weak correlation) allow for an easy verification of the obtained results. In the case where all the real properties have identical values of the attributes which they have been described by, the arithmetic mean of all the elements of the analyzed time series can be assumed to be the market value of the real estate with the characteristics identical to the real estates in the database. It amounts to $1.15 \pm 0.54 \mathrm{PLN} / \mathrm{m}^{2}$, and it is comparable to the value obtained by the forecast made with the use of time series (1.34 PLN/m²).

\section{Summary}

To sum up, it is worth trying to objectively assess the proposed method of the analysis of variance of unit transaction prices in time and to determine the market value. According to the authors, it could be adopted as the method of examining trends in the real estate market based on large data sets, when the differences in the characteristics describing their individual elements are insignificant. Using time series to determine the direction of changes alone may considerably 
enhance the knowledge of the mechanisms governing local real estate markets. Estimation of the market value by this method is, however, a big challenge. The assumptions adopted in this work (the scaling of the attributes allowing to describe a wide base of real properties with identical characteristics) allowed for the rapid implementation of this task. However, in reality, the valuation by forecasting methods using time series would be very laborious. The collection and preparation of data for the valuation would be very time-consuming. In addition, a necessity to use arduous algorithms and specialized software for the calculations would discredit this method among real property valuers.

\section{References}

[1] Adamczewski Z.: Elementy modelowania matematycznego w wycenie nieruchomości: podejście porównawcze. Oficyna Wydawnicza Politechniki Warszawskiej, Warszawa 2006.

[2] Box G.E.P., Jenkins G.M.: Analiza szeregów czasowych: prognozowanie i sterowanie [transl. from Eng. by W. Herer]. Państwowe Wydawnictwo Naukowe, Warszawa 1983.

[3] Brockwell P.J., Davis R.A.: Introduction to time series and forecasting. Springer-Verlag, New York 1996.

[4] Czaja J.: Metody szacowania wartości rynkowej i katastralnej nieruchomości. KOMP-SYSTEM, Kraków 2001.

[5] Frukacz M., Popieluch M., Preweda E.: Korekta cen nieruchomości ze wzgledu na uptyw czasu w przypadku dużych baz danych. Infrastruktura i Ekologia Terenów Wiejskich, nr 4, 2011, pp. 213-226.

[6] Hamilton J.D.: Time series analysis. Princeton University Press, Princeton 1994.

[7] Klajn J.: Analiza trendu zmian cen nieruchomości w czasie. Geomatics and Environmental Engineering, vol. 1, no. 2, 2007, pp. 45-58.

[8] Powszechne Krajowe Zasady Wyceny (PKZW). Nota interpretacyjna. Zastosowanie podejścia porównawczego w wycenie nieruchomości. Polska Federacja Stowarzyszeń Rzeczoznawców Majątkowych. [on-line:]

http://pfsrm.pl/do-pobrania [access: 15.06.2015].

[9] Pawlukowicz R.: Metoda porównywania parami z wykorzystaniem statystyczno-ekonometrycznego modelowania zmian cen w czasie. Studia i Materiały Towarzystwa Naukowego Nieruchomości, vol. 17, no. 1, 2009, pp. 14-30.

[10] Pawlukowicz R.: Wykorzystanie koncepcji kombinowanych quasi-prognoz do aktualizacji danych w rynkowych modelach wyceny nieruchomości. Prace Naukowe Akademii Ekonomicznej we Wrocławiu, nr 988, Klasyfikacja i analiza danych - teoria i zastosowania, t. 10, Wydawnictwo Akademii Ekonomicznej we Wrocławiu, Wrocław 2003, pp. 491-500. 
[11] Rozporzadzenie Rady Ministrów z dnia 21 września 2004 r. w sprawie wyceny nieruchomości i sporzadzania operatu szacunkowego. Dz.U. nr 207 poz. 2109 as amended.

[12] Ustawa z dnia 21 sierpnia 1997 r. o gospodarce nieruchomościami. Dz.U. nr 115 poz. 741 as amended.

[13] Trojanek R.: Wpływ wahań koniunkturalnych na lokalne rynki mieszkaniowe. Studia i Materiały Towarzystwa Naukowego Nieruchomości, vol. 18, no. 1, 2010, pp. 81-94.

[14] Wiśniewski R., Identification of nonstationarity type in time series of land property prices in Poland. Studia i Materiały Towarzystwa Naukowego Nieruchomości, vol. 19, no. 1, 2011, pp. 33-47. 